\title{
Retraction Note: Normal families of solutions for modified equilibrium equations and their applications
}

Yili Tan' ${ }^{1}$ Weiyong Ding ${ }^{2}$, Yourong Wang ${ }^{3}$ and Zongjing Jiang 4* $^{*}$

The original article can be found online at https://doi.org/10.1186/ s13661-017-0906-6

${ }^{*}$ Correspondence: zong.jiang@gmx.us

${ }^{4}$ School of Computer Science, Hunan Industry and Trade University, Changsha, 412006, China Full list of author information is available at the end of the article

\section{Retraction note}

The Editors-in-Chief have retracted this article [1] because its results are invalid. It also shows considerable overlap with an article by Lu and Sun [2] that was simultaneously under consideration. Additionally, the article shows evidence of authorship manipulation. The authors have not responded to any correspondence regarding this retraction.

\section{Author details}

${ }^{1}$ College of Science, North China University of Science and Technology, Tangshan, 063210, China. ${ }^{2}$ School of Mathematics and Statistics, Jiangsu Normal University, Xuzhou, 221116, China. ${ }^{3}$ Department of Basic, Tangshan College, Tangshan, 063000, China. ${ }^{4}$ School of Computer Science, Hunan Industry and Trade University, Changsha, 412006, China.

\section{Publisher's Note}

Springer Nature remains neutral with regard to jurisdictional claims in published maps and institutional affiliations.

Published online: 19 July 2020

\section{References}

1. Tan, Y., Ding, W., Wang, Y., et al.: Normal families of solutions for modified equilibrium equations and their applications. Bound. Value Probl. 2017, 176 (2017). https://doi.org/10.1186/s13661-017-0906-6

2. Lu, Y., Sun, J.: A new technique to study the boundary behaviors of superharmonic multifunctions and their application. Bound. Value Probl. 2017, 144 (2017). https://doi.org/10.1186/s13661-017-0874-x sharing, adaptation, distribution and reproduction in any medium or format, as long as you give appropriate credit to the original author(s) and the source, provide a link to the Creative Commons licence, and indicate if changes were made. The images or other third party material in this article are included in the article's Creative Commons licence, unless indicated otherwise in a credit line to the material. If material is not included in the article's Creative Commons licence and your intended use is not permitted by statutory regulation or exceeds the permitted use, you will need to obtain permission directly from the copyright holder. To view a copy of this licence, visit http://creativecommons.org/licenses/by/4.0/. 